\title{
THE USE OF FIELD DATA FROM THE FAULTED MARGIN OF THE GULF OF CORINTH AS INPUT TO THE RESERVOIR MODEL OF THE LAVRANS FIELD, HALTENBANKEN, OFFSHORE NORWAY
}

\author{
E. SVERDRUP ${ }^{1}$, T. SKOV ${ }^{2}$, M. SOLHEIM ${ }^{3}$, E. AARSETH ${ }^{4}$ AND R. H. GABRIELSEN ${ }^{5}$
}

\begin{abstract}
Large proportions of the structural features that can impact on the flow properties of a reservoir are below the resolution of seismic data. Understanding the spatial distribution and internal structure of faults is therefore fundamental. By using a field analogue from the southern margin of the Gulf of Corinth, we have obtained information about fault parameters like frequency, orientation and linkage, which have been used in the reservoir modelling process of the Lavrans Field, offshore Norway. The link between field observations, seismic interpretation and plaster modelling techniques has further guided us to describe the structural development of the investigated structures.
\end{abstract}

KEY WORDS: fault geometry; internal block deformation; reservoir modelling.

\section{INTRODUCTION}

Use of field analogues have been recognised as an important element in reservoir modeling, which include basic activities such as seismic interpretation and $3 \mathrm{D}$ geological modeling. At a finer scale, field analogues provide data for sedimentological architecture and small-scale deformation by faults, as well as calibration of fluid flow parameters. Data from field analogue studies (structural- and sedimentological) can therefore be used in order to constrain input to reservoir modeling tools.

In this paper we focus on the use of field analogue data for structural modeling purposes. We show that field data from the southern margin of the Gulf of Corinth can be used to guide and constrain the construction of a three-dimensional reservoir model of the Lavrans Field located in the Haltenbanken area, offshore Norway.

\section{FIELD ANALOGUE (THE GULF OF CORINTH)}

The west-northwest oriented Miocene to Recent Gulf of Corinth Basin separates the northern coast of the peninsula of Peloponnese from the rest of the Greece mainland (Figure 1). Towards the east, the basin is separated from the Saronic Gulf by the uplifted Isthmus area. Towards the northeast the basin gradually shallows, and the throw of the faults diminishes (e.g. Roberts \& Jackson 1991, Poulimenos \& Doutsos 1997). The western part of the basin narrows and the structure is overtaken by the Gulf of Patras. The areas to the south of the present day gulf exhibit a dramatic topography, caused by the rapid (and periodic) uplift and block rotations that occurred as the response to major fault movements (e.g. Kelletat et al. 1976, LePichon \& Angelier 1979, Billiris et al. 1991, Papazachos \& Kiratzi 1996). A series of faults arranged in an en-echelon pattern, and which partly are situated in the present day gulf, bound the high relief along the southern coast. Each of these segments is between 15 and $25 \mathrm{~km}$ long and has an average strike of $\mathrm{N} 090^{\circ}-105^{\circ}$ (Armijo et al. 1996).

Quatenary sediments exposed in the uplifted areas to the south consist of thick lacustrine and deltaic sequences that prograde towards the north. In general, these sediments are subdivided into alluvial fans and lacustrine conglomerates to the south, Gilbert-type fan deltas in the centre, and lacustrine to marine carbonates to the north (Doutsos \& Piper 1990, Dart et al. 1994). The Gulf of Corinth is seismically active today and the interplay between sedimentological and tectonic processes is obvious.

1. Roxar Software Solutions, P.O.Box 165 Skwyen, N-0212 Oslo, Norway

2. Schlumberger Stavanger Research, P.O.Box 8013, N-4068 Stavanger, Norway

3. University of Bergen, Alligt. 41, 5007 Bergen

4. Norsk Hydro ASA, P.O. Box 7190 Sandsli, 5020 Bergen

5. University of Bergen, Allıt. 41, 5007 Bergen 


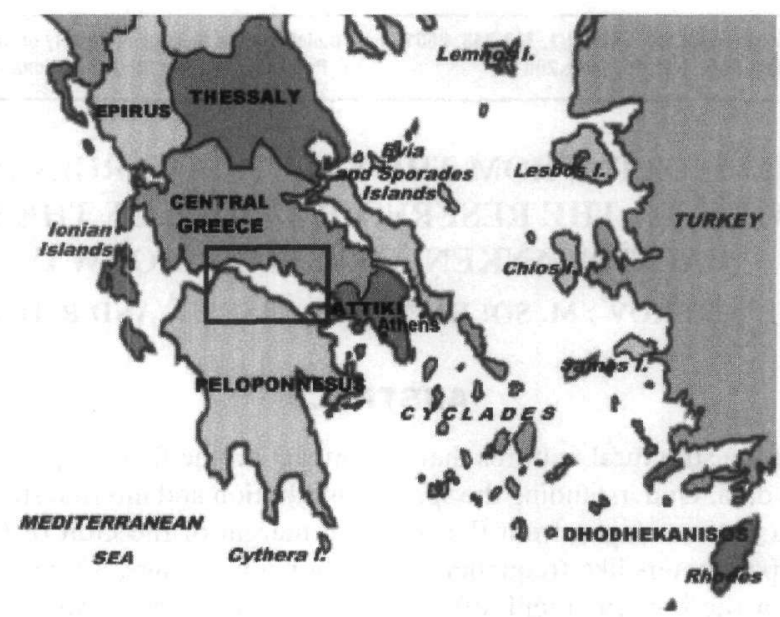

Figure 1. Location map, Gulf of Corinth basin, Greece.

Field data from the Gulf of Corinth have been collected within the framed area displayed in Figure 2. Major faults and basement-cover relationships are shown on the profile in Figure 3 (see also Doutsos \& Poulimenos 1992, Dart et al. 1994, Poulimenos 2000). The area is characterised by southerly tilted fault blocks segmented by east-west and north-south trending faults. The size of each fault block is typically in the range between 50 and $200 \mathrm{~km}^{2}$.

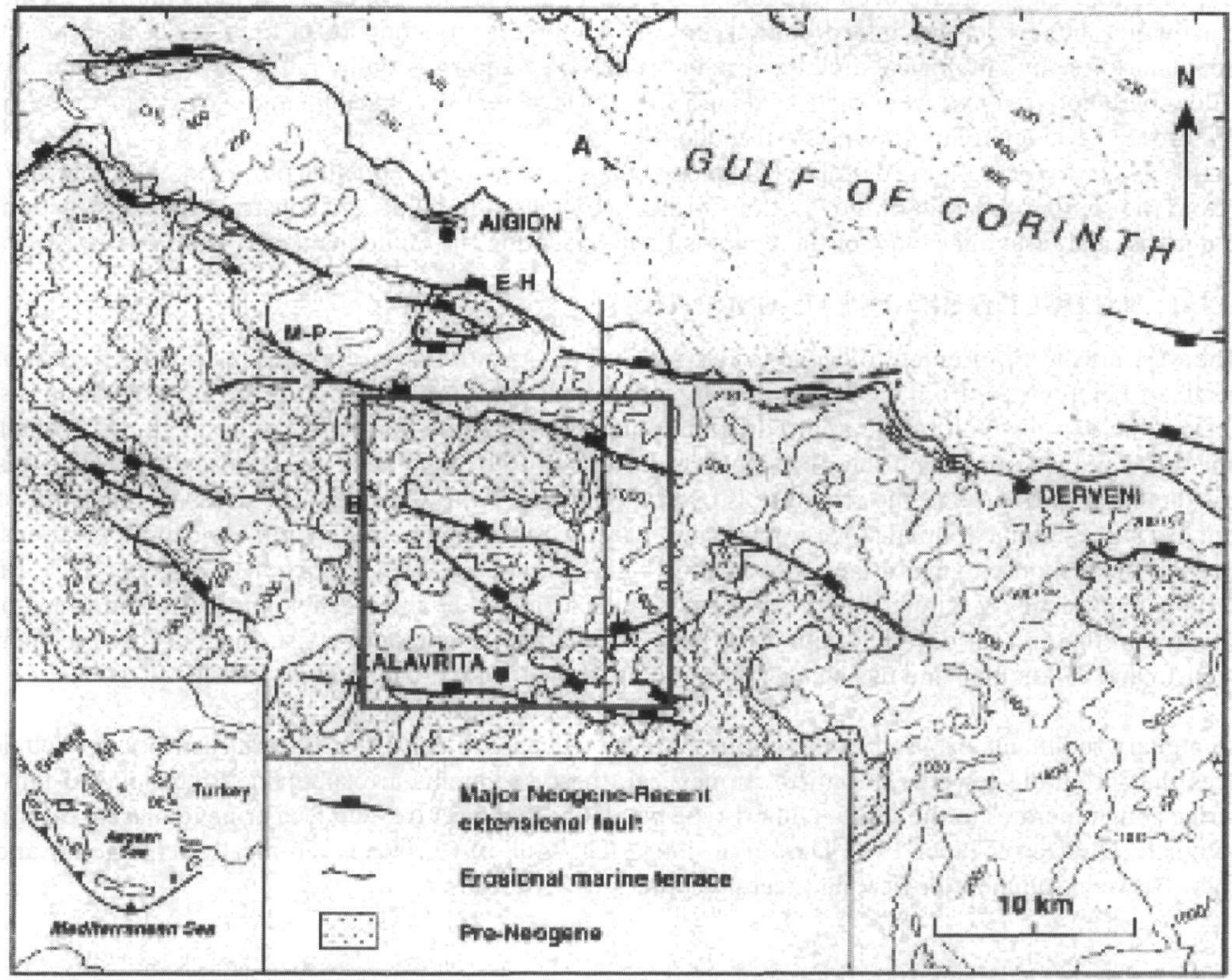

Figure 2. Map of the studied area modified from Dart et al. (1994). Fieldwork has been carried out within the framed area located between Kalavrita (south) and the present coastline (north). North-south oriented profile is sketched in Figure 3. 


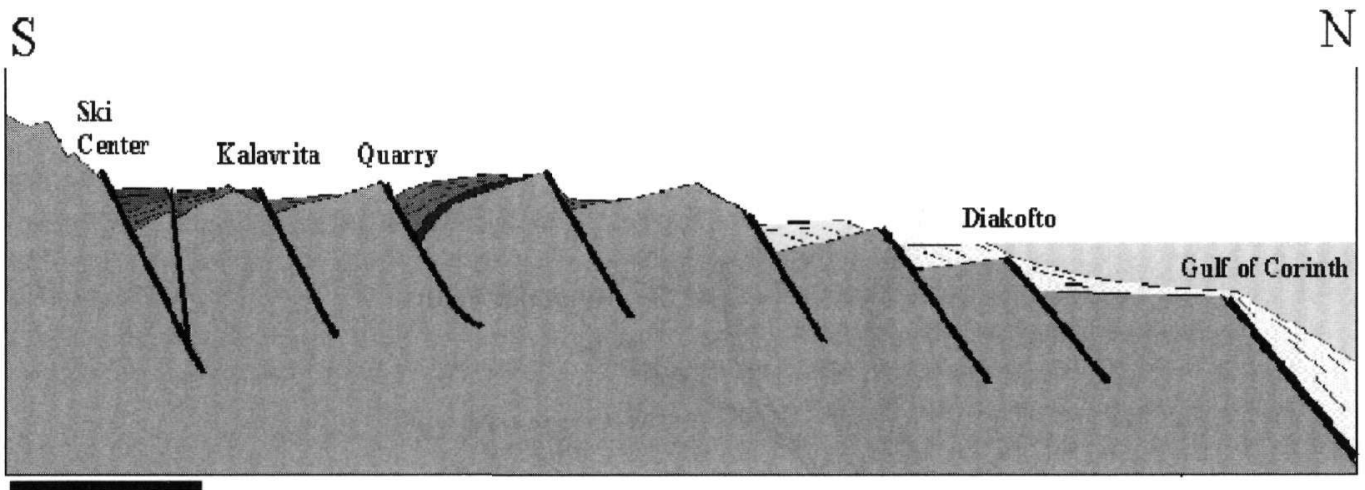

$5 \mathrm{~km}$

Figure 3. Profile located on Figure 2 that illustrates the overall tectonic architecture of the studied area. Basement rocks (gray colour) is situated beneath a sediment cover with thickness variations that results from varying sedimentation processes as well as erosion.

\section{THE RESERVOIR (LAVRANS FIELD, HALTENBANKEN)}

The Lavrans Field represents a structurally well-defined hydrocarbon trap located in the Haltenbanken area, offshore mid-Norway (Figure 4). The field is defined by an easterly tilted, north-south striking fault block, restricted to the east and west by the Trestakk and Sm $\psi$ rbukk faults, respectively (Figure 5). The Trestakk Fault is segmented in two strands that link in the central part of the Lavrans structure, and display dip-slip normal displacement in the order of 1000 meters. In its deeper parts the Trestakk Fault links with the Sm $\psi$ rbukk Fault, which exhibits a vertical separation of approximately 1200 meters. The dominant intra-structure fault trend follow the main block bounding faults. A subsidiary fault trend is observed to strike almost east-west.

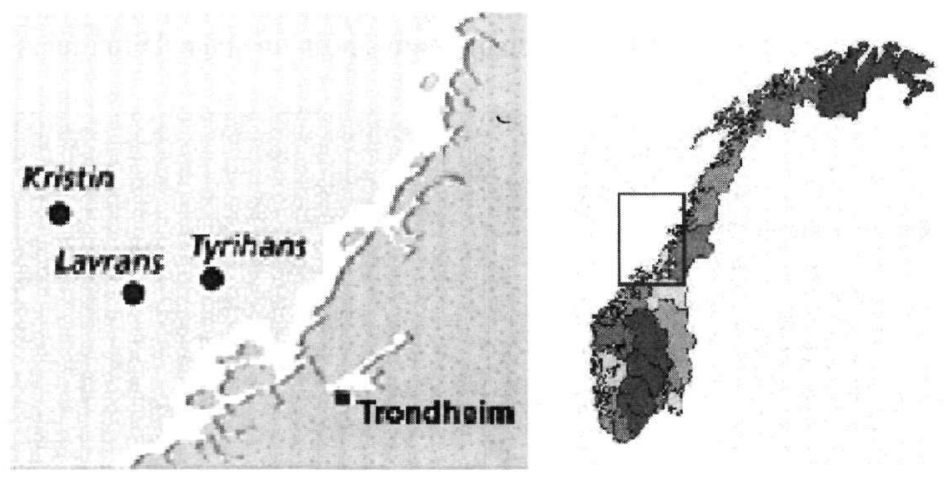

Figure 4. Location map of the Lavrans Field, offshore mid-Norway.

The stratigraphic dips are on average $25^{\circ}$ but show variations between $10^{\circ}$ and $40^{\circ}$. This variation seems to be closely linked to the geometry of the underlying Trestakk Fault. In general, the stratigraphic dips increase from north to south, positively correlated with the amount of crestal deformation (Figure 5). The present depth of the Lavrans Field is between 3000 to 3500 meters. Wells drilled on the Lavrans structure confirm that the structure has a high degree of internal deformation. Throw values of intra-structure faults that are observed from the ordinary seismic data, typically are in the order of 50 to 100 meters. Seismic attribute dip maps have been utilised for the purpose of identifying additional fault structures. However, the variation of deformation across the field, as well as the spatial distribution of the fault parameters (e.g. orientation, dip, population and throw, together with the 3D-fault connectivity) could not be resolved properly by the current seismic and well data. In order to increase the accuracy of the fault model of Lavrans, it was decided to use a field analogue from the Gulf of Corinth. 
Figure 5. A schematic map of the main structural elements associated with the Lavrans Field. The two cross sections illustrates the change in dip from north to south and how a large detachment has developed beneath structure in the south.

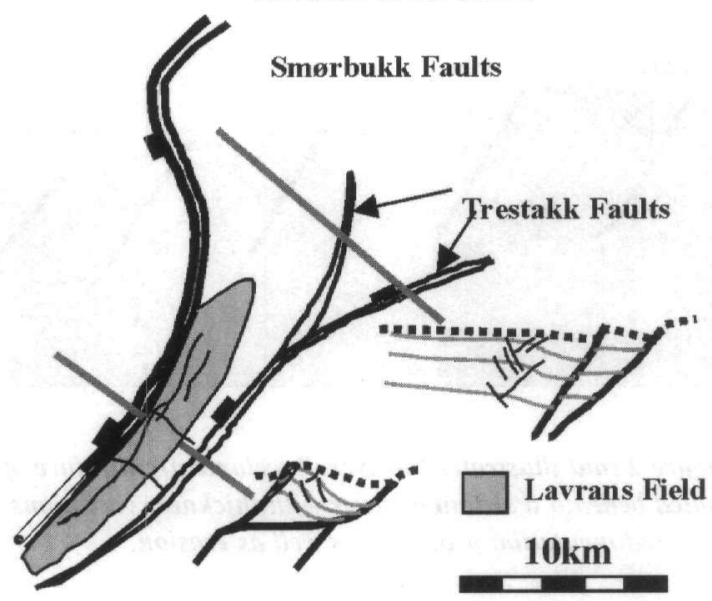

\section{USE OF FIELD ANALOGUE DATA FOR GEOLOGICAL MODELS OF THE LAVRANS FIELD}

Figure 6 compares a west-east seismic profile of the Lavrans fault block (above) with a north-south profile through the field analogue from the Gulf of Corinth (below). As shown by this figure, both fault blocks are strongly rotated towards the underlying, major faults (Trestakk and Quarry faults). On a large scale, a gradual decreasing dip is recorded in the stratigraphy as one move towards the crestal parts of the blocks. 'Both structures show evidence of crosscutting intra-block faults with comparable throw values. The field analogue was used to provide important information regarding fault frequencies, spatial distribution and orientations, which can be utilised in the structural modelling process of the Lavrans field.

One important difference between the Gulf of Corinth and the Haltenbanken area is the fact that the Corinth graben is an active structure whereas Haltenbanken undergo a post-rift stage. Differences are also recorded

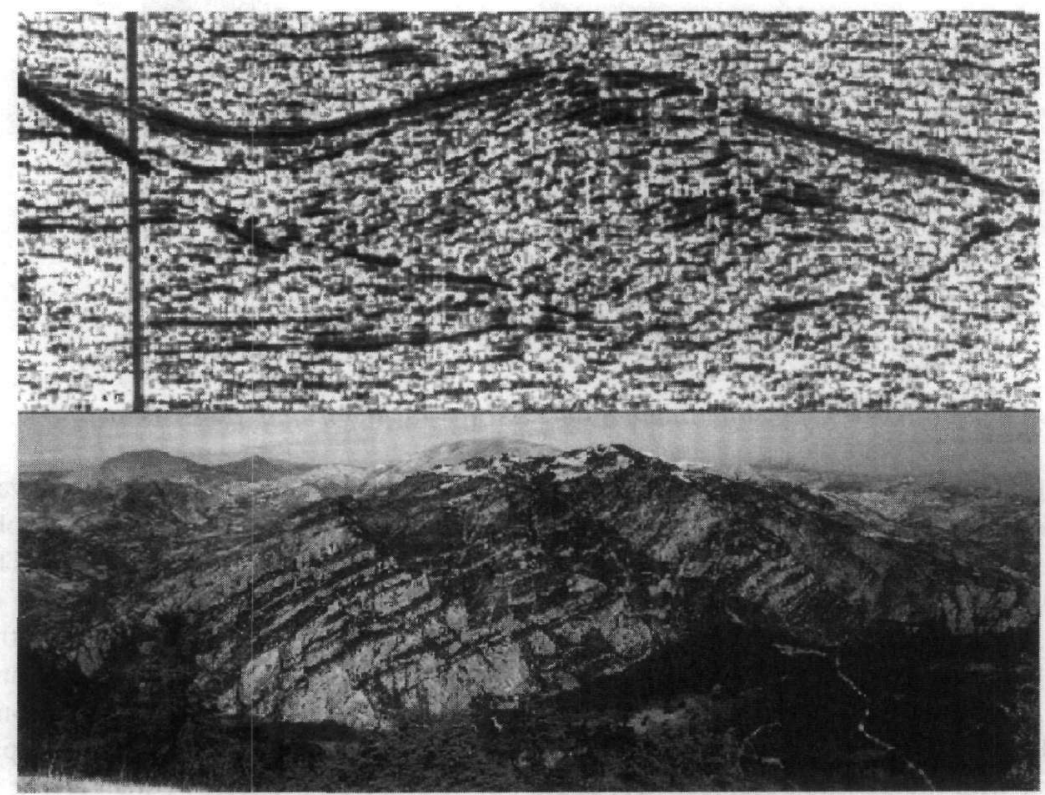

Figure 6. Top: East - West profile through the Lavrans fault block. Bottom: South - North profile through a fault block near Kalavrita. 
in the structural and stratigraphical expressions. Firstly, the floor fault of the Lavrans fault block detaches above the top of the basement. Hence, it comprises sediments only. In contrast, the field analogue exhibits eroded basement outcrops along its crest indicating that the master detachment is within the basement. Secondly, siliciclastic sediments dominate the Lavrans field, whereas the field analogue predominantly consists of clastic carbonates.

\section{INTERNAL DEFORMATION (THE LAVRANS FIELD)}

Two horizons (Top Garn Formation and Top Ile Formation) were mapped in detail and analysed with respect to lineaments and fault offsets. Dip attributes of the horizons were focussed in the analyses.

The diagrams in Figure 7 show the fieldwide fault frequency distribution of intra-structure faults parallel to the strike of the Sm $\psi$ rbukk and Trestakk faults. The fault block is subdivided into a western part that represents the faults in the footwall of the Sm $\psi$ rbukk Fault (crestal part of the Lavrans structure) and an eastern part that is dominated by the deformation in the hangingwall of the Trestakk Fault (deeper parts of the Lavrans structure). Figure 8 shows the distribution of displacement and length values for the intra-block faults of the Lavrans Field. Both parameters indicate a better correlation factor (straight line on a log-log plot) for the Top Garn reflector compared to the diagrams from the Top Ile reflector. The orientation distribution of the intra-block faults is shown in Figure 9. By comparing the orientations with the trends of the main faults (the Smభrbukk and Trestakk faults), it is obvious that the small-scale faults in general follow the trends given by the main faults.
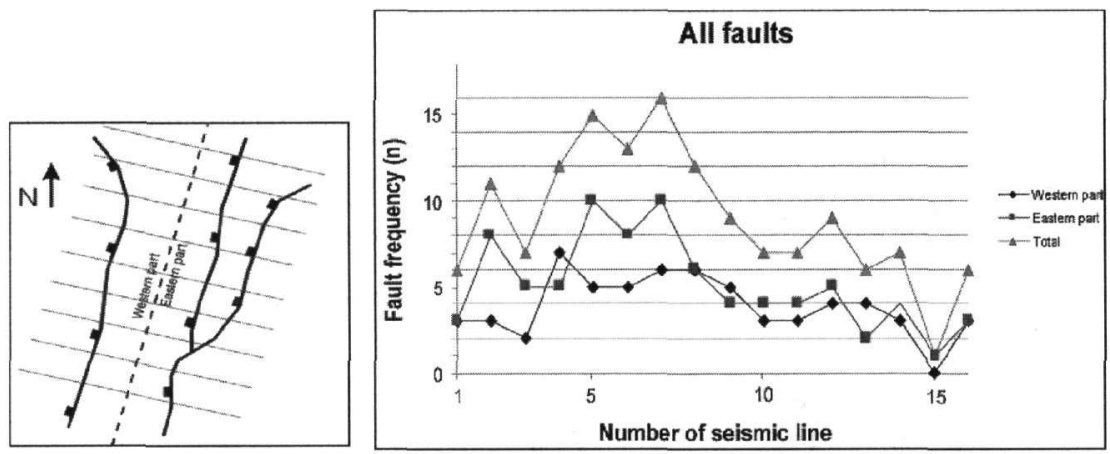

Figure 7. Spatial distribution of faults in the Lavrans field. (A) Data were collected from 16 seismic cross lines and divided in to a western and eastern part (separated by the stippled line). (B) All faults plotted together (triangles). The number of faults in the eastern part (squares) dominates slightly over the western part (diamonds).

a) Top Garn (Fault displacement)

a)

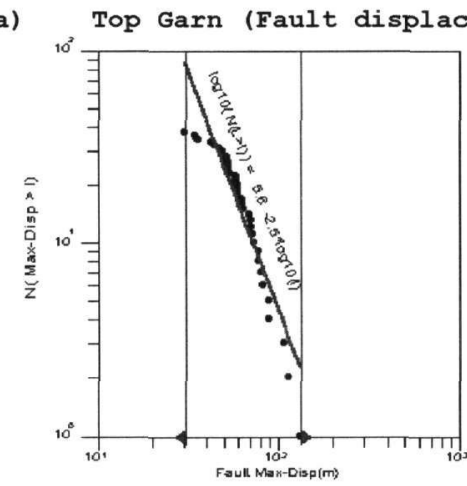

b) Top Ile (Fault

b) Top Ile (Fault displacement)

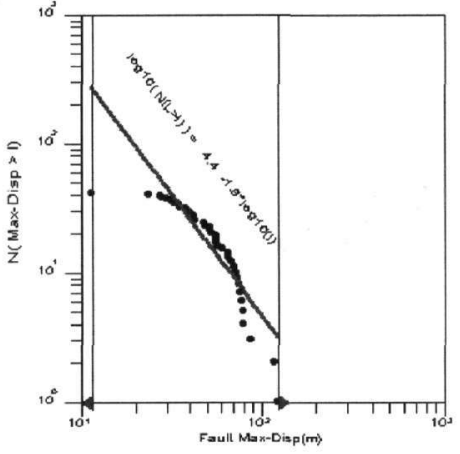

Figure 8. Maximum displacement of faults plotted against cumulative number for a) Top Garn and b) Top Ile. 
a

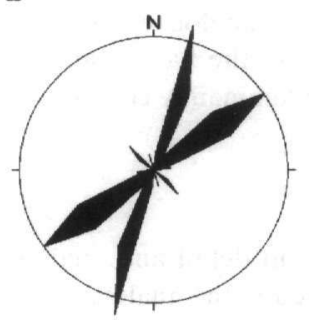

b

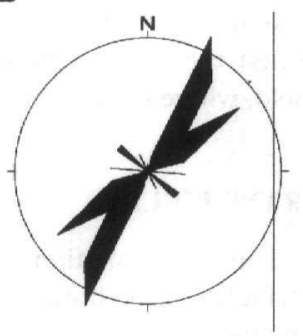

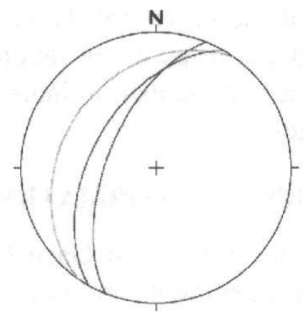

Figure 9. Rose plots (bi-directional) for faults at (a) Top Garn and (b) Top Ile. The plots show that NNE-SSW and NE-SW are the dominating fault trends. A subordinate population is oriented NW-SE. (c) Fault planes of the

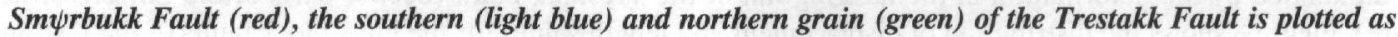
great circles for comparison.

\section{INTERNAL DEFORMATION (THE FIELD ANALOGUE)}

The main objective from the field analogue mapping was to obtain information about the spatial distribution and frequencies of small-scale faults, in order to use this information in the reservoir modelling work of Lavrans. Fracture frequency was studied along horizontal and vertical scan-lines across the fault block (Figure 10). It was shown that small-scale faults and fractures tend to exhibit very consistent trends guided by the large-scale blockbounding faults (Figure 11).

The fieldwork also focussed on the strain distribution within and around relay ramps, and the three-dimensional linking of faults. In addition, much work was concentrated on the structural development of the fault blocks. For this purpose dynamic plaster models were created. The resulting models that mimic the development of the field analogue have been compared with the overall structure of the Lavrans Field.

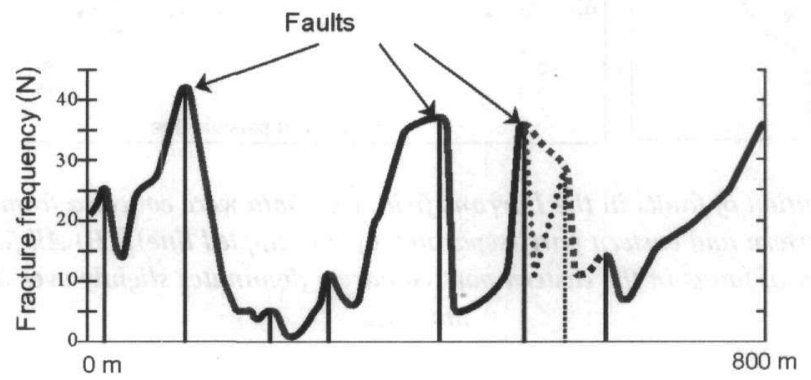

Figure 10. Fault frequency along a north-south oriented scan-line. The diagram shows the elevated densities of fractures close to intra-block fault (damage zones). The damage zones are asymmetric and display higher frequencies in the hangingwall blocks compared to the footwall blocks.
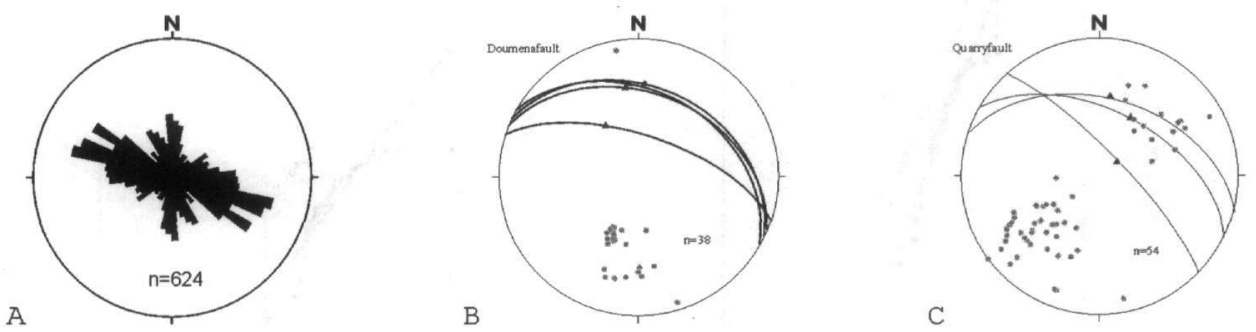

Figure 11. With the exception of a subordinate trend oriented ' $N-S$, the orientation distribution of small-scale faults and fractures within the fault block (a) follows the trends of the major faults (b) and (c). 


\section{CONCLUSIONS AND CONSEQUENCES FOR RESERVOIR MODELLING}

A common but important assumption made in fault seal analyses is that fault throw as determined in reflection seismic data is accommodated across one single fault. This study demonstrate that fault zones are composed of asymmetrical damage zones that must be accounted for in the reservoir modeling process.

The importance of establishing relationships between large- and small-scale structures is obvious for the purpose of quantifying the number of structural features that develop during the deformation of a volume. By the use of fault population data from the field analogue, we are able to model the frequency and spatial distribution of subseismic faults in the Lavrans reservoir.

3D orientation distributions of structural features are certainly important for the modelling of fluid flow within reservoirs, as the non-parallel members of the arrays induce an intersection network which will control the connectivity of barriers. The field data from the Gulf of Corinth enable us to implement realistic properties for fault orientations and lengths in the Lavrans Field.

The integration between detailed seismic interpretation, field analogue data sampling, as well as plaster modelling, has indeed improved the reservoir model of the Lavrans Field.

\section{REFERENCES}

ANGELIER, J. 1978. Tectonic evolution of the Hellenic Arc since the late Miocene. Tectoniphysics 49, 23-36. ARMIJO, R., MEYER, B., KING, G.C.P., RIGO, A. \& PAPANASTASSIOU, D. 1996. Quarternary evolution of the Corinth Rift and its implications for the Late Cenozoic evolution of the Aegean. Geophys. Journ. Int., 126, 1, 11-53.

BILLIRIS, H., PARADISSIS, D., VEIS, G., ENGLAND, P., FEATHERSTONE, W., PARSONS, B., CROSS, P., RANDS, P., RAYSON, P., SELLERS, P., ASHKENAZI, V., DAVISON, M., JACKSON, J. \& AMBRASEYS, N. 1991. Geodetic determination of tectonic deformation in central Greece from 1900 to 1988 . Nature 350, 124-129.

DART, C.J., COLLIER, R.E.LL., GAWTHORPE, R.L., KELLER, J.V.A. \& NICHOLS, G. 1994. Sequence stratigraphy of (?)Pliocene - Quarternary synrift, Gilbert-type fan deltas, Northern Peloponnesos, Greece. Marine and Petroleum Geology 11, 5, 545-560.

DOUTSOS,T. \& PIPER, D.W. 1990. Listric faulting, sedimentation, and morphological evolution of the Quarternary eastern Corinth rift, Greece: First stages of continental rifting. Geol. Soc. Of America Bull. 102, 812-829.

DOUTSOS, T. \& POULIMENOS, G. 1992. Geometry and kinematics of active faults and their seismotectonic significance in the western Corinth - Patras rift (Greece). Journ. Struct. Geol. 14, 6, 689-699.

KELLETAT, D., KOWALCZYK, G., SCHRÖDER, B. \& WINTER, K.P. 1976. A synoptic view on the neotectonic development of the Peloponnesian coastal regions. Z. Dtsch. Ges. 127, 447-465.

LE PICHON, X. \& ANGELIER, J. 1979. The Hellenic arc and trench system: a key to the neotectonic evolution of the eastern Mediterrenean area. Tectonophysics 60, 1-42.

PAPZACHOS, C.B. \& KIRATZI, A.A. 1996. A detailed study of the active crustal deformation in the Aegean and surrounding area. Tectonics 253, 129-153.

POULIMENOS, G. 2000. Scaling properties of normal fault populations in the western Corinth Graben, Greece: implications for fault growth in large strain settings. Journal of Structural Geology 22, 307-322.

POULIMENOS, G. \& DOUTSOS, T. 1997. Flexural uplift of rift flanks in central Greece. Tectonics 16, 912-923.

ROBERTS, S. \& JACKSON, J. 1991. Active normal faulting in central Greece: an overview. In: Roberts, A. M., Yielding, G. \& Freeman, B. (eds.), The geometry of Normal Faults, Geological Society of London Special Publication 56, 125-142. 